\title{
High grade metamorphism in the Bundelkhand massif and its implications on Mesoarchean crustal evolution in central India
}

\author{
S P Singh ${ }^{1, *}$ and S B Dwivedi ${ }^{2}$ \\ ${ }^{1}$ Department of Geology, Bundelkhand University, Jhansi 284 128, India. \\ ${ }^{2}$ Department of Civil Engineering, Indian Institute of Technology (Banaras Hindu University), \\ Varanasi 221 005, India. \\ ${ }^{*}$ Corresponding author.e-mail: spsinghbu@rediffmail.com
}

The Bundelkhand Gneissic Complex (BnGC) in the central part of the Bundelkhand massif preserves a supracrustal unit which includes pelitic (garnet-cordierite-sillimanite gneiss, garnet-sillimanite gneiss, biotite gneiss and garnet-biotite gneiss) and mafic (hornblende-biotite gneiss and garnetiferous amphibolite) rocks. Granulite facies metamorphism of the complex initiated with breaking down of biotite to produce garnet and cordierite in the pelitic gneisses. Geothermobarometric calculations indicate metamorphic conditions of $720^{\circ} \mathrm{C} / 6.2 \mathrm{kbar}$, followed by a retrograde $\left(687^{\circ} \mathrm{C} / 4.9 \mathrm{kbar}\right)$ to very late retrograde stages of metamorphism $\left(579^{\circ} \mathrm{C} / 4.4 \mathrm{kbar}\right)$ which is supported by the formation of late cordierite around garnet. The $\mathrm{P}-\mathrm{T}$ conditions and textural relations of the garnet-cordierite-bearing gneiss suggest a retrograde cooling path of metamorphism.

\section{Introduction}

The Bundelkhand massif is an important cratonic block in the central Indian shield which is separated from the Chhotanagpur Granite Gneiss Complex and Bastar Craton in the south by the east-west trending Son-Narmada lineament, from the Aravalli Fold Belt in the west, by the NESW trending Great Boundary Fault (GBF), and from the Gangetic Plains in the north by the WNW-ESE trending Yamuna fault (Singh et al. 2007; Basu 2010). Garnet-sillimanite-cordieritebearing ganulite facies supracrustal rocks have been reported from the central part of Bundelkhand massif (Singh and Dwivedi 2009). These rocks are associated with tonalitic-trondhjemite-granodiorite (TTG) gneisses exposed around Mauranipur (figure 1) and are grouped in the Bundelkhand Gneissic Complex (BnGC) (Singh et al. 2007; Mohan et al. 2012). Available radiometric age suggests that the TTG rocks were formed during Mesoarchean (Mondal et al. 2002) and were subsequently emplaced into high grade metamorphic rocks (Mohan et al. 2012). Apart from this, high pressure metamorphism reported by Saha et al. (2011) of Mg-Al-rich white schist has opened up new possibilities to constrain the variations in the metamorphic conditions in the Archaean Bundelkhand Craton. In this study, we present the mineralogy, microtextural relations and pressure (P)-temperature $(\mathrm{T})$ evolution of granulite facies supracrustal rocks around Mauranipur area and discuss their significance in Archean crustal evolution of the Bundelkhand Craton.

Keywords. Metamorphism; granulite; Bundelkhand massif; supracrustal rocks; crustal evolution. 


\section{Geological setting}

The Bundelkhand massif covers an area of about $26,000 \mathrm{~km}^{2}$ in central India with a semicircular outline (Basu 1986). It is occupied by a vast expanse of hornblende-, biotite- and leuco-granitoids (the Bundelkhand Granite), within which TTG gneisses and high grade supracrustals of pelitic, psammitic, mafic and ultramafic lithologies (BnGC), and low grade supracrustals of banded-magnetitequartzite and metavolcanic association (BMM) occur as slivers and narrow belts (Sharma 2000; Mondal 2010; Mohan et al. 2012) (figure 1). In the central part of the massif, slivers of BnGC and BMM occur together and more or less parallel to each other with general E-W trend (Singh 2012a). The BnGC rocks are strongly deformed with folding of at least five generations (Bhattacharya 1986; Prasad et al. 1999). In contrast, the BMM rocks are relatively less deformed and show three phases of folding. The entire Bundelkhand massif is traversed by numerous NE-SW trending quartz veins and quartz reefs along the NE-SW trending crustal scale shear system (Bhattacharya and Singh 2013) and NW-SE trending mafic dyke swarms (Rao et al. 2005; Pradhan et al. 2012).

The available geochronological data on TTG of the Bundelkhand Craton include:

- whole rock $\mathrm{Sm}-\mathrm{Nd}$ isochron age of $3298 \pm 11 \mathrm{Ma}$ from Mahoba area (Sharma and Rahman 1995);

- whole rock Rb-Sr isochron age of $3503 \pm 99 \mathrm{Ma}$ from Babina area (Sarkar et al. 1996);

- ion microprobe $\mathrm{Pb}-\mathrm{Pb}$ zircon age of $3189 \pm 5 \mathrm{Ma}$ from Lalitpur area (Mondal et al. 1998);

- ion microprobe $\mathrm{Pb}-\mathrm{Pb}$ zircon ages of $3297 \pm 8 \mathrm{Ma}$ and $3270 \pm 3 \mathrm{Ma}$ for gneisses near Mauranipur and Mahoba, respectively, and $3249 \pm 5 \mathrm{Ma}$ for
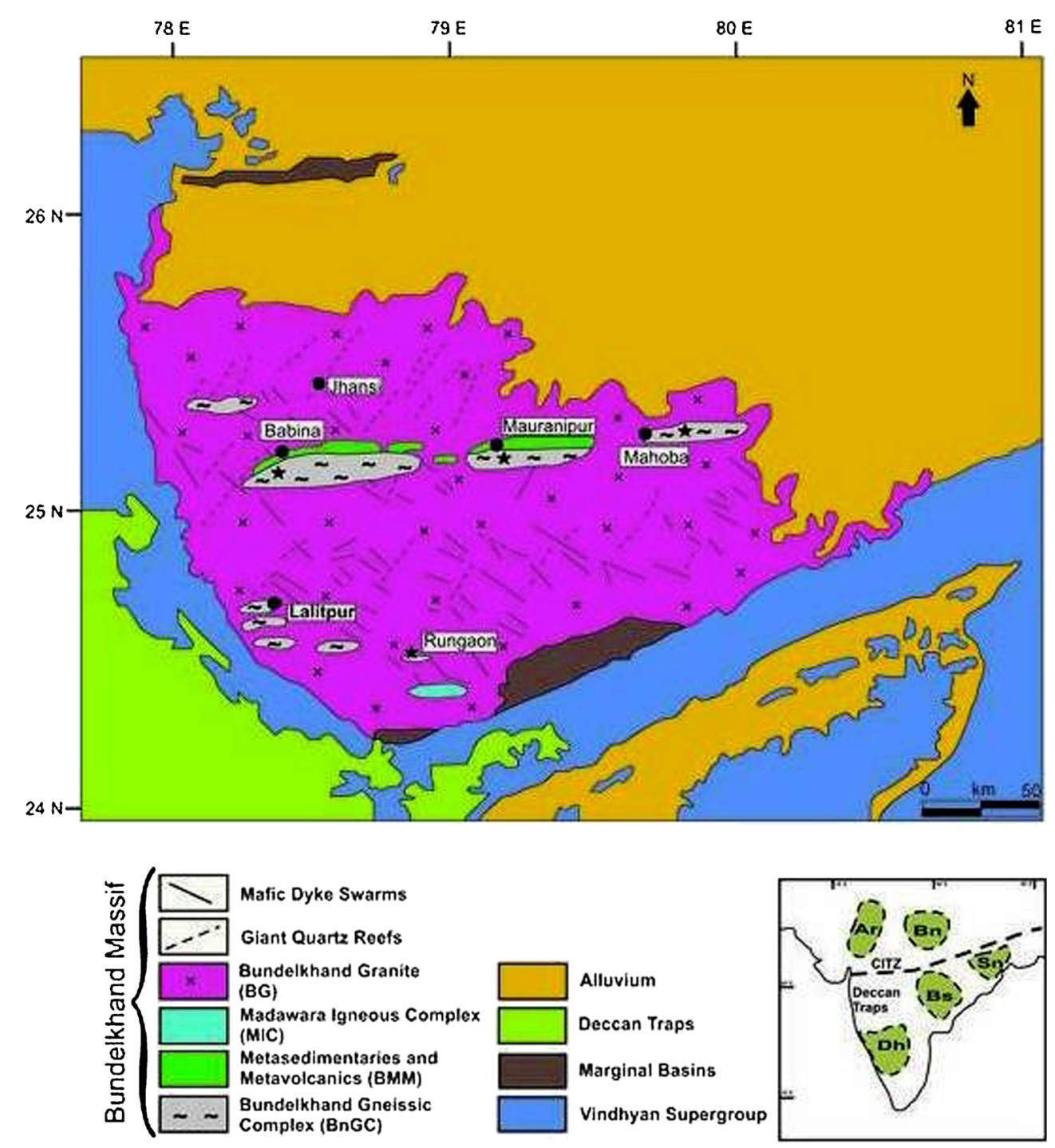

Figure 1. A generalized geological and tectonic map of the Bundelkhand Craton (after Basu 1986; Singh et al. 2007; Mohan et al. 2012). 
amphibolites near Mahoba (Mondal et al. 2002); and

- SHRIMP U-Pb zircon age of 3291 \pm 5 Ma (Kumar et al. 2011). These data indicate that the occurrence of TTG is an important event in the Bundelkhand massif during 3.1-3.3 Ga.

Broadly coeval TTG rocks have been reported from other cratons of the Indian shield including the Rajasthan Craton (Wiedenbeck and Goswami 1994), the Dharwar Craton (e.g., Peucat et al. 1993), and the Singhbhum Craton (e.g., Acharyya et al. 2010). Recently few occurrences of metamorphosed pelitic rocks from Bundelkhand Craton associated with TTG have been described (Singh and Dwivedi 2009; Saha et al. 2011). From the $\mathrm{Mg}-\mathrm{Al}$-rich white schist in the Babina area, a well constrained age $\sim 2800 \mathrm{Ma}(2789 \pm 49 \mathrm{Ma}$, U$\mathrm{Th}-\mathrm{Pb}$ monazite and LA-ICPMS U-Pb zircon date, Saha et al. 2011) is the only available metamorphic age that comes from the high pressure metamorphic rocks. Not much information is available for the event of high-grade metamorphism of supracrustal rocks; however, based on the intrusive field relationships of TTGs, the granulite facies metamorphism is attributed to Mesoarchaean event (Singh 2012a). Subsequent to high grade metamorphism, an $\mathrm{E}-\mathrm{W}$ trending greenstone belt consisting mafic volcanism, banded-magnetite formation, and felsic volcanism (also known as BMM, Singh et al. 2007) was developed in the central part during Neoarchean (Mondal 2010; Pandey et al. 2011; Singh 2012b). The post-greenstone evolutionary stage of Bundelkhand Craton is marked by the large scale granitic activities and cratonization which is interpreted to be $\sim 2.5 \mathrm{Ga}$ based on the $\mathrm{U}-\mathrm{Pb}$ and $\mathrm{Pb}-\mathrm{Pb}$ ages of the granitoids (Mondal et al. 1998, 2002; Kumar et al. 2011).

\subsection{Lithology and structure of Mauranipur area}

The BnGC rocks at the central part of the Bundelkhand Craton appear as an E-W trending septum at the junction of two large granitic batholiths, i.e., coarse-grained grey granite (CGG), and medium-grained grey granite (MGG) in the north and coarse-grained pink granite (CPG), medium-grained pink granite (MPG), and finegrained pink granite (FPG) in the south. The Bundelkhand Gneissic Complex has its western margin at Babina to the south of Jhansi town and is continuously traceable eastwards through Pura, Gora, Balyara, Simra, Pirthipur to Mauranipur for about $77 \mathrm{~km}$ in length in the central part of craton (figure 1).

The Mauranipur area is located in the central part of Bundelkhand massif, where the BnGC rocks are exposed for the most part, while BMM rocks occur locally (figure 2). The terrain is characterized by a more or less subdued topography except for the ESE-WNW trending small isolated hillocks of banded magnetite quartzite and a NE-SW trending quartz reef near Kuraicha village. Garnet-sillimanite gneiss, garnetcordierite-sillimanite gneiss, garnet-biotite gneiss, biotite-sillimanite gneiss, calc-silicate gneiss, hornblende-biotite gneiss, amphibolite, garnetiferous amphibolite, garnet-hornblende-biotite gneiss, quartzite, granitic gneiss and migmatite are the major BnGC rock types in the study area. Amphibolite and hornblende-biotite gneiss usually occur in the form of bands or lenticular patches within pelitic gneiss and are cofolded with them (figure 3a, c). Pelitic gneisses often show well developed banding represented by leucosomes and melanosomes of variable thicknesses (figure $3 \mathrm{~b}, \mathrm{~d}$ ). Small lenses of garnet-hornblende-biotite gneiss and garnetiferous amphibolite are also observed in the pelitic gneiss, where coarse to very coarse grained reddish brown garnet is embedded in the dark coloured matrix of amphibole minerals. In the Saprar river section, the TTG rocks exhibit intrusive relationship with amphibolite and pelitic gneiss. The presence of $2-3 \mathrm{~m}$ thick lensoidal bodies of pelitic gneiss within the TTG (Mohan et al. 2012) is a good agreement to support the statement that high grade metamorphism is an older event than TTG emplacement.

In general, foliations in the gneisses strike NWSE to WNW-ESE and dip steeply $\left(>70^{\circ}\right)$ towards NE-NNE. Four phases of deformation $\mathrm{D}_{1}-\mathrm{D}_{4}$ are identified in the area. The first three phases are recorded as mesoscopic folds of $\mathrm{F}_{1}, \mathrm{~F}_{2}$ and $\mathrm{F}_{3}$ generations, respectively, whereas the $\mathrm{D}_{4}$ deformation has resulted in the development of shear structures in the rocks. Tight to isoclinal folds $\left(\mathrm{F}_{1}\right)$ with NW-SE to E-W striking axial planes and plunging towards NW are observed in the hornblendebiotite gneiss. The folds of $\mathrm{F}_{2}$ generation are tight to closed in nature with NNW-SSE axial trend (figure $3 \mathrm{~b}, \mathrm{c}, \mathrm{d}$ ), and are locally coaxial with $\mathrm{F}_{1}$ folds. $F_{3}$ folds are usually broad warps. The $\mathrm{D}_{4}$ deformation is recorded by $\mathrm{S}-\mathrm{C}$ fabric (figure $3 \mathrm{f}$ ), sheath folds, and small scale vertical shear zones. This deformation is considered to be synchronous with the regional scale $\mathrm{E}-\mathrm{W}$ trending vertical shearing in the central part of Bundelkhand massif (Basu 2010; Singh and Bhattacharya 2010).

\section{Petrography}

Mineral assemblages in the pelitic and mafic rocks of the BnGC are given in table 1 . The minerals present in different pelitic assemblages include cordierite, garnet, biotite, sillimanite, K-feldspar, 


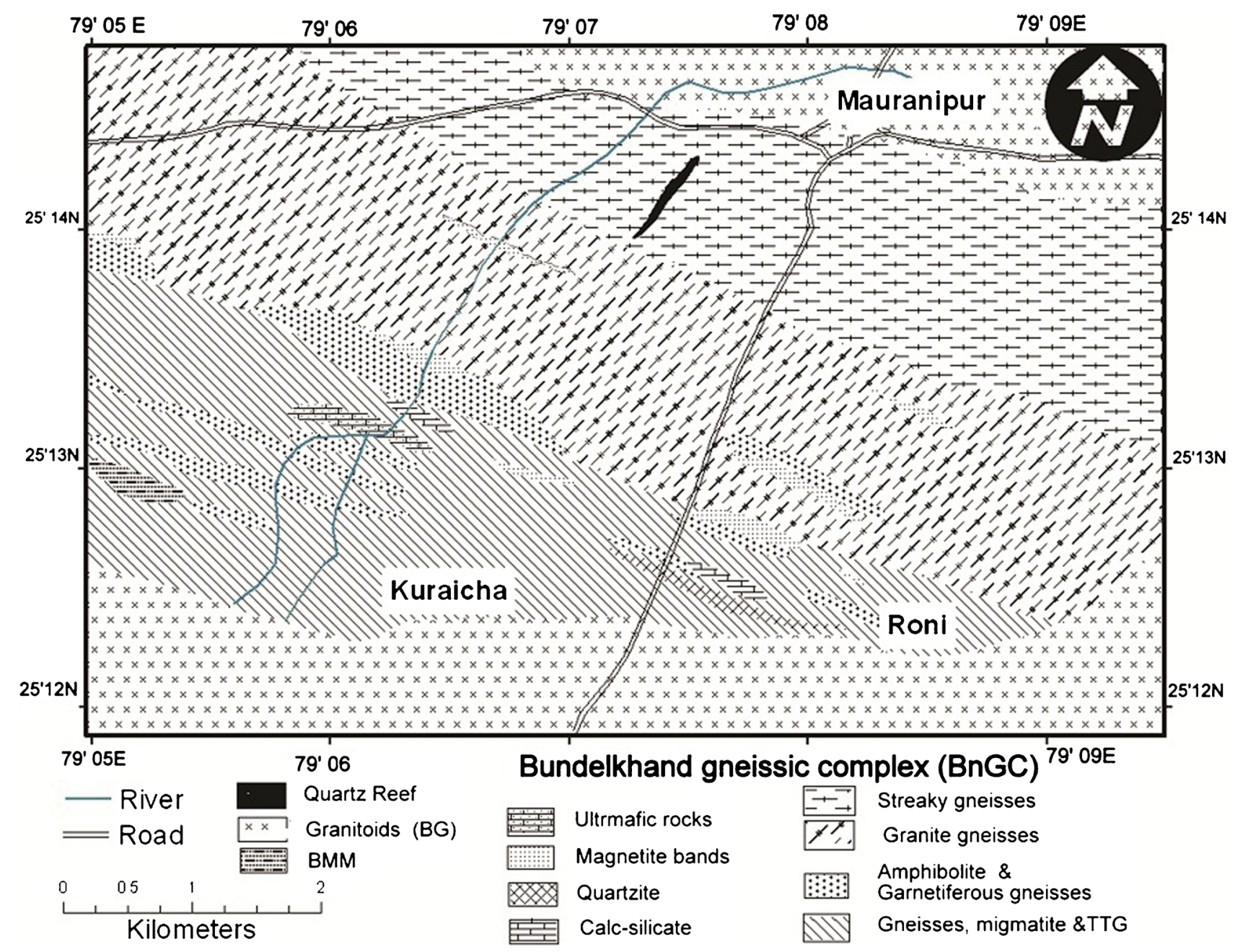

Figure 2. Geological map of the area around Mauranipur, Bundelkhand Craton showing the distribution of various litho units.

plagioclase, and quartz, whereas those in the mafic rocks include garnet, clinopyroxene, hornblende, biotite, plagioclase, and quartz. Apatite and magnetite are present as accessory phases in both the lithologies. The broad petrographic characteristics of these rocks are outlined below. The mineral abbreviations used in this paper are - alm: almandine; bt: biotite; cpx: clinopyroxene; crd: cordierite; grs: grossularite; grt: garnet; hbl: hornblende; kfs: K-feldspar; liq: liquid; mt: magnetite; plag: plagioclase; prp: pyrope; sil: sillimanite; sps: spessartite, and qtz: quartz.

\subsection{Pelitic rocks}

Cordierite shows yellow pleochroic haloes and is highly pinitised (figure 4a, c, d). Biotite is commonly pleochroic in shades of reddish brown. In garnetiferous gneisses that lack in cordierite and sillimanite, biotite is pleochroic from pale yellow to greenish brown (figure 4b). Sillimanite commonly occurs as aggregates of small acicular grains.
Sometimes, fibrolitic sillimanite appears to grow from biotite (figure 4c). K-feldspar is commonly perthitic. Both K-feldspar and plagioclase show considerable sericitisation.

In some samples, garnet occurs as poikiloblasts with numerous inclusions of quartz (figure $4 \mathrm{~b}$ ). In others, garnet porphyroblasts locally contain inclusions of biotite, sillimanite, and quartz. The garnet-cordierite assemblage (figure 4a) is interpreted to have formed by the reaction:

$$
\begin{aligned}
\text { Biotite } & + \text { sillimanite }+ \text { quartz } \leftrightarrow \text { cordierite }_{1} \\
& + \text { garnet }+\mathrm{K} \text {-feldspar }+\mathrm{H}_{2} \mathrm{O} \text { in melt. }
\end{aligned}
$$

This is a reaction which marks the entry of pelites into the granulite facies during prograde metamorphism. In some samples, garnet occurs as corroded relict within cordierite (figure 4d). This cordierite, which is texturally late, is likely to have formed by the reaction:

Garnet + sillimanite + quartz $\leftrightarrow$ cordierite $_{2} \ldots$ 

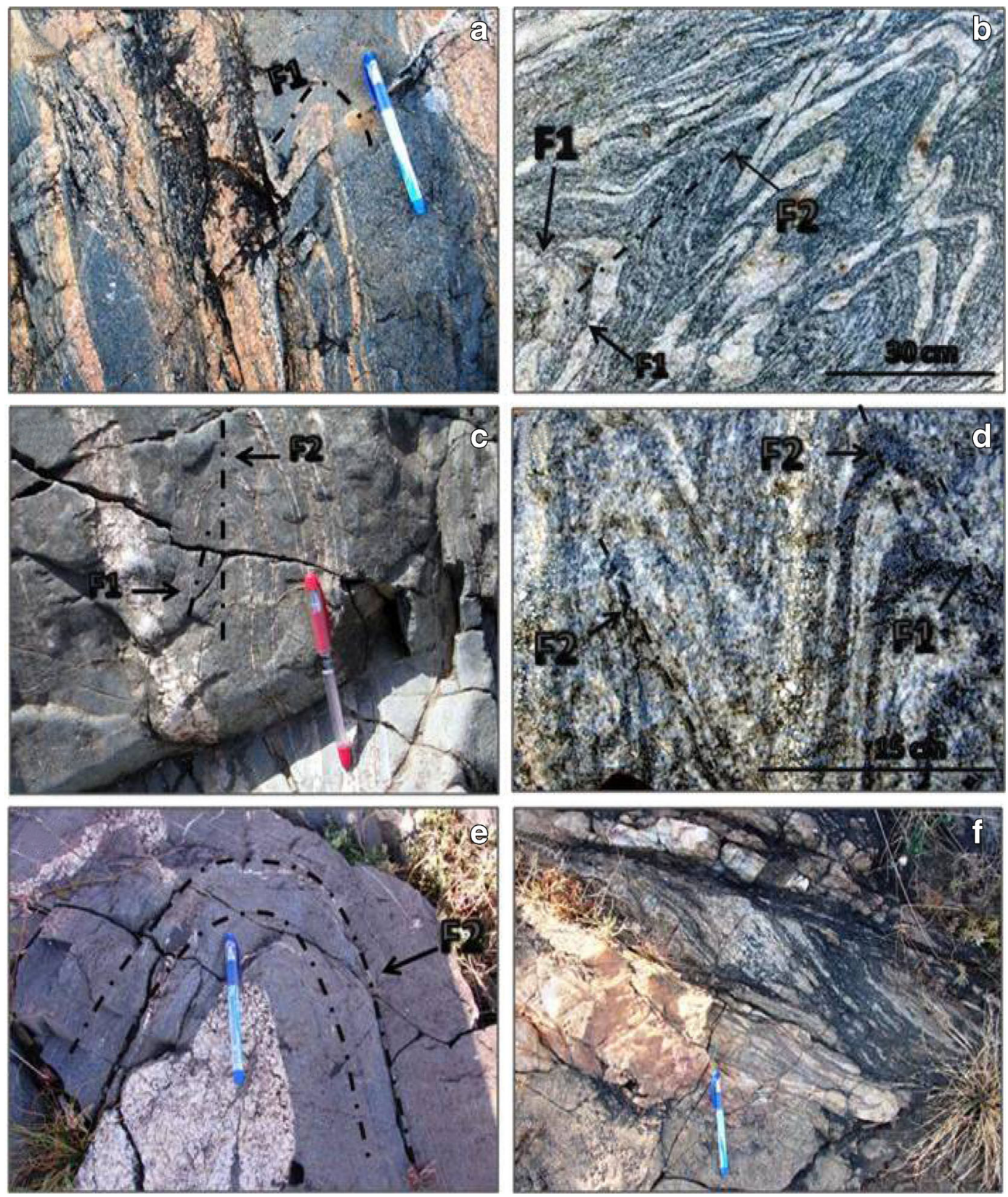

Figure 3. Field photographs showing: (a) interbanding of amphibolite and pelitic gneiss, both involved in deformation and metamorphism; (b) $\mathrm{F}_{1}$ and $\mathrm{F}_{2}$ folds in pelitic gneiss; (c) tight $\mathrm{F}_{2}$ folds in amphibolite; (d) tight $\mathrm{F}_{2}$ folds in pelitic gneiss; (e) closed $\mathrm{F}_{2}$ antiform in amphibolite with intrusion of TTG at the core; (f) $\mathrm{S}-\mathrm{C}$ frabric in pelitic gneiss related to $\mathrm{D}_{4}$ deformation.

Textural relations suggest that the cordierite is different from the cordierite ${ }_{2}$ but the analytical data of the cordierite ${ }_{1}$ have been interpreted in the present study.

\subsection{Mafic rocks}

Hornblende is the dominant mineral in the assemblages of mafic rocks (figure $4 \mathrm{e}, \mathrm{f}, \mathrm{g}, \mathrm{h}$ ). Its pleochroism varies from shades of bluish green (figure 4h) to shades of yellowish green (figure 4e, f). The mineral often contains inclusions of quartz and biotite. Preferred orientation of hornblende defines the foliation in some samples (figure 4h); while in others the mineral shows decussate texture (figure $4 \mathrm{~g}$ ). Garnet in the amphibolites is coarse grained and mainly associated with hornblende and plagioclase. In some amphibolites, garnet occurs as poikiloblasts with numerous inclusions of hornblende, magnetite and quartz. Garnet in hornblende-biotite gneiss occurs as anhedral grains, which are highly fractured and locally replaced by late hornblende and biotite (figure 4e). 
Table 1. Mineral assemblages of pelitic and mafic gneisses of BnGC from Mauranipur area.

\begin{tabular}{|c|c|c|c|c|c|c|c|c|c|}
\hline \multirow{2}{*}{$\begin{array}{l}\text { Rock type } \\
\text { Sample no./Minerals }\end{array}$} & \multicolumn{4}{|c|}{ Metapelites } & \multicolumn{5}{|c|}{ Metabasites } \\
\hline & $\overline{\mathrm{M} 232}$ & M34 & M257 & M239 & M38 & M35 & M37 & M 247 & M148 \\
\hline Garnet & $\sqrt{ }$ & $\sqrt{ }$ & & & $\sqrt{ }$ & $\sqrt{ }$ & $\sqrt{ }$ & & \\
\hline Biotite & $\sqrt{ }$ & $\sqrt{ }$ & $\sqrt{ }$ & $\sqrt{ }$ & $\sqrt{ }$ & $\sqrt{ }$ & $\sqrt{ }$ & $\sqrt{ }$ & \\
\hline Sillimanite & $\sqrt{ }$ & $\sqrt{ }$ & $\sqrt{ }$ & $\sqrt{ }$ & & & & & \\
\hline Cordierite & $\sqrt{ }$ & & $\sqrt{ }$ & & & & & & \\
\hline K-feldspar & $\sqrt{ }$ & $\sqrt{ }$ & $\sqrt{ }$ & $\sqrt{ }$ & $\sqrt{ }$ & $\sqrt{ }$ & & $\sqrt{ }$ & \\
\hline Plagioclase & $\sqrt{ }$ & $\sqrt{ }$ & $\sqrt{ }$ & $\sqrt{ }$ & $\sqrt{ }$ & $\sqrt{ }$ & $\sqrt{ }$ & $\sqrt{ }$ & $\sqrt{ }$ \\
\hline Quartz & $\sqrt{ }$ & $\sqrt{ }$ & $\sqrt{ }$ & $\sqrt{ }$ & $\sqrt{ }$ & $\sqrt{ }$ & $\sqrt{ }$ & $\sqrt{ }$ & \\
\hline Hornblende & & & & & $\sqrt{ }$ & $\sqrt{ }$ & $\sqrt{ }$ & $\sqrt{ }$ & $\sqrt{ }$ \\
\hline Clinopyroxene & & & & & & & & & $\sqrt{ }$ \\
\hline Magnetite & $\sqrt{ }$ & $\sqrt{ }$ & & $\sqrt{ }$ & $\sqrt{ }$ & $\sqrt{ }$ & $\sqrt{ }$ & $\sqrt{ }$ & $\sqrt{ }$ \\
\hline Apatite & $\sqrt{ }$ & & $\sqrt{ }$ & & & $\sqrt{ }$ & & & \\
\hline Ilmenite & & $\sqrt{ }$ & $\sqrt{ }$ & $\sqrt{ }$ & $\sqrt{ }$ & $\sqrt{ }$ & $\sqrt{ }$ & $\sqrt{ }$ & \\
\hline Rutile & $\sqrt{ }$ & & & & $\sqrt{ }$ & $\sqrt{ }$ & $\sqrt{ }$ & $\sqrt{ }$ & $\sqrt{ }$ \\
\hline Zircon & $\sqrt{ }$ & $\sqrt{ }$ & $\sqrt{ }$ & & & & & & \\
\hline
\end{tabular}

\section{Mineral chemistry}

Mineral chemistry of coexisting phases has been determined by a JEOL-JXA-8600M electron probe micro analyzer at the Indian Institute of Technology, Roorkee. Operating conditions were: acceleration voltage $15 \mathrm{kV}$, probe current 20-50 $\mathrm{nA}$, and beam diameter $\sim 2 \mu \mathrm{m}$. Both natural and synthetic standards were used. Analyses of plagioclase, biotite, cordierite, hornblende, and garnet are given in table $2(\mathrm{a}-\mathrm{e})$.

\subsection{Feldspar}

Chemical composition of plagioclase is quite uniform (table 2a). Anorthite contents range from $\mathrm{An}_{40}$ to $\mathrm{An}_{50}$ in the metapelites. In mafic gneisses, the anorthite content of plagioclase is very high $\left(\mathrm{An}_{83}\right)$ when compared with metapelites.

\subsection{Biotite}

Biotite has variable $\mathrm{TiO}_{2}$ content ranging from 1.25 to $1.71 \mathrm{wt} \%$. The $\mathrm{X}_{\mathrm{Mg}}(\mathrm{Mg} / \mathrm{Mg}+\mathrm{Fe})$ of biotite ranges between 0.521 and 0.528 for garnetcordierite-sillimanite gneisses, 0.334 and 0.351 for the biotite gneisses, and 0.345 and 0.375 for the hornblende-biotite gneisses (table 2b). All the biotites show a certain alkali deficiency that is highest in the garnet-cordierite gneisses $(\Sigma Y=1.226$ to 1.751), lowest for the garnet-hornblende-biotite gneisses $(\Sigma Y=1.674$ to 1.860$)$ and garnet-biotite gneisses $(\Sigma Y=1.879$ to 1.948$)$ (table $2 b)$. The $\mathrm{Al}_{2} \mathrm{O}_{3}$ content ranges from 17.33 to $18.06 \mathrm{wt} \%$ for garnet-cordierite gneisses, 15.98-16.40 wt\% for biotite-sillimanite-gneisses while it is 15.95$16.30 \mathrm{wt} \%$ for garnet-hornblende-biotite gneisses.
Similarly the $\mathrm{Al}^{\mathrm{VI}}$ ranges from 0.669 to 0.904 p.f.u. for garnet-cordierite-sillimanite gneisses and from 0.491 to 0.566 for biotite-sillimanite gneisses.

\subsection{Garnet}

Garnet considerably differs in composition in different rock types. Garnet grains from metapelites are richer in almandine $\left(\mathrm{Alm}_{60-75} \mathrm{Sps}_{1-7}\right.$ $\operatorname{Prp}_{5-25} \mathrm{Grs}_{5-25}$ ), whereas the garnets from mafic gneisses are rich in grossularite in comparison of minimum content $\left(\mathrm{Alm}_{63-69} \mathrm{Sps}_{4-7} \mathrm{Prp}_{5-7} \mathrm{Grs}_{16-23}\right)$. Garnets from these gneisses have moderate and relatively constant values of spessartine. The coarsegrained and early-formed garnet in cordieritesillimanite gneiss is usually rich in $\mathrm{MgO}$ and $\mathrm{MnO}$. The granular aggregate of garnets which are involved in the formation of cordierite has usually moderate content of pyrope. This indicates that the Mg-rich garnet was involved in the formation of cordierite. The garnet in biotite-gneisses have high mole $\%$ of spessartite and grossularite up to $25 \mathrm{~mole} \%$ and low pyrope content. Garnets from these gneisses have wide range of chemical compositions depending upon the bulk chemistry of the rocks and also the composition of coexisting mineral parageneses and metamorphic condition.

\subsection{Cordierite}

Cordierite contains mainly $\mathrm{SiO}_{2}, \mathrm{Al}_{2} \mathrm{O}_{3}, \mathrm{FeO}$, and $\mathrm{MgO}$. The larger cations are nearly absent. The $\mathrm{Na}_{2} \mathrm{O}$ content is less than $1 \mathrm{wt} \% . \mathrm{X}_{\mathrm{Mg}}$ of cordierite ranges from 0.646 to 0.649 . Total oxides never exceed $98 \%$ indicating the presence of fluid in the channels of the crystal structure. 

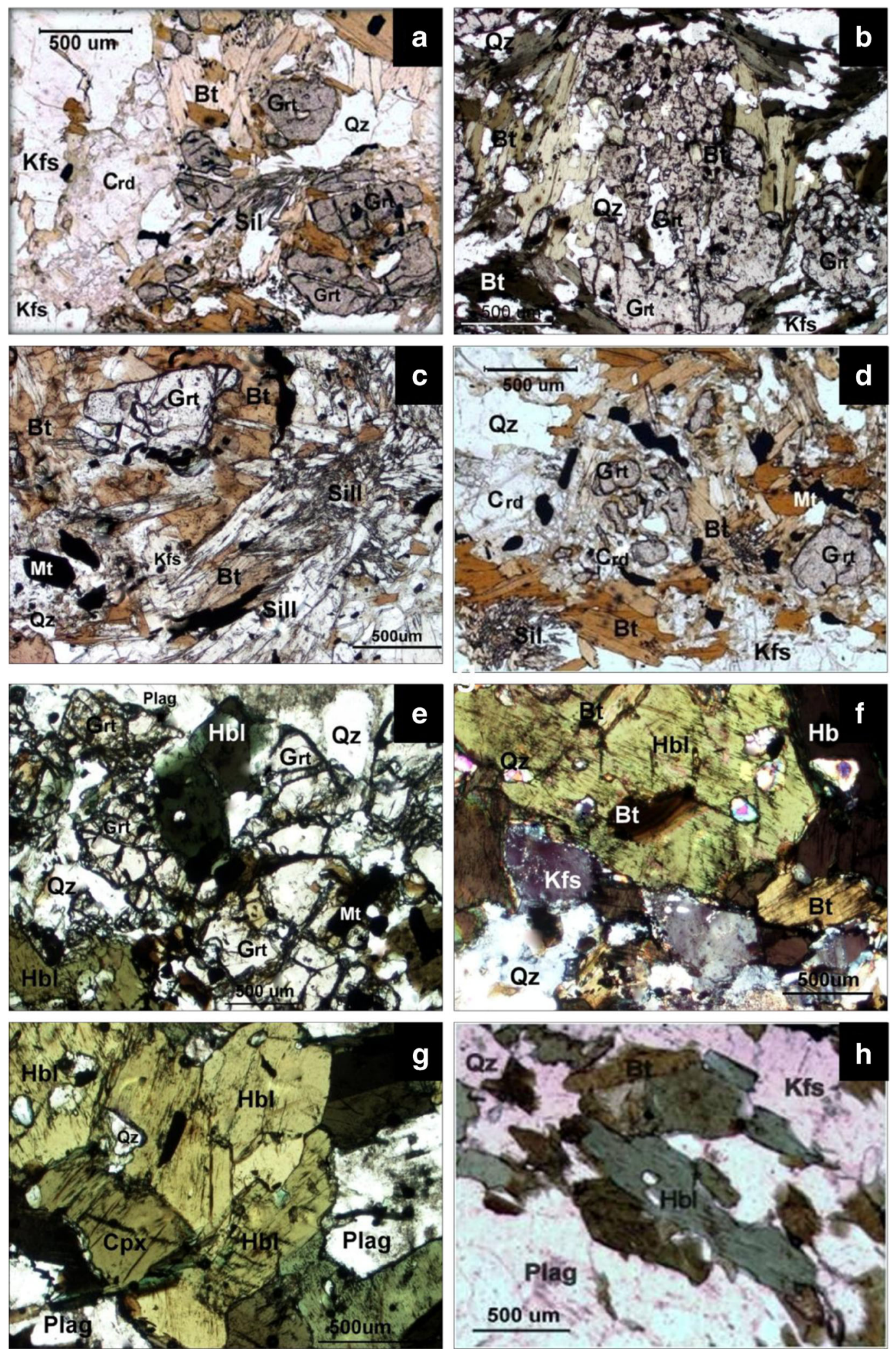

Figure 4. Photomicrographs of BnGC rocks from the Mauranipur area. (a) garnet-cordierite-sillimanite-biotite-K-feldspar assemblage in pelitic gneiss; (b) garnet-biotite gneiss showing sieved texture of garnet porphyroblast due to numerous inclusions of quartz; the inclusions trail in garnet are inclined to the foliation in the matrix; (c) biotite being replaced by fibrolitic sillimanite in pelitic gneiss; (d) anhedral relicts of garnet in cordierite in pelitic gneiss; (e) highly fractured garnet in garnet-hornblende gneiss; late hornblende and biotite replace granet along fractures; (f) hornblende-biotite gneiss showing biotite inclusions in hornblende; (g) decussate texture shown by hornblende grains in amphibolite; (h) hornblendebiotite gneiss showing preferred orientation of hornblende; all photomicrographs except (f) are under plane polarized light; (f) is under crossed nicols. The bar represents the magnification of photomicrograph. 
Table 2. Electron microprobe analytical data of coexisting phases from garnet-cordierite-sillimanite gneisses, garnetsillimanite-biotite gneisses and garnet-hornblende-biotite gneisses of Mauranipur area.

(a) EPMA data of plagioclase.

\begin{tabular}{|c|c|c|c|c|c|c|c|}
\hline \multirow{2}{*}{$\begin{array}{l}\text { Rock type } \\
\text { Sample no. }\end{array}$} & \multicolumn{6}{|c|}{ Metapelites } & \multirow{2}{*}{$\begin{array}{l}\text { Metabasite } \\
\text { M38/C1/1 }\end{array}$} \\
\hline & $\overline{\mathrm{M} 232 / \mathrm{c} 1}$ & $\mathrm{M} 232 / \mathrm{c} 1 / 2$ & M34/c1 & $\mathrm{M} 34 / \mathrm{c} 2$ & M34/c3 & $\mathrm{M} 34 / \mathrm{c} 6$ & \\
\hline $\mathrm{SiO}_{2}$ & 55.82 & 55.78 & 57.53 & 57.74 & 56.80 & 57.76 & 42.69 \\
\hline $\mathrm{Al}_{2} \mathrm{O}_{3}$ & 27.08 & 27.42 & 25.97 & 26.12 & 26.89 & 25.93 & 30.20 \\
\hline $\mathrm{CaO}$ & 8.71 & 9.27 & 9.07 & 9.07 & 9.07 & 9.07 & 21.64 \\
\hline $\mathrm{Na}_{2} \mathrm{O}$ & 6.38 & 6.34 & 6.86 & 6.75 & 6.53 & 7.01 & 2.52 \\
\hline $\mathrm{K}_{2} \mathrm{O}$ & 0.06 & 0.06 & 0.07 & 0.04 & 0.05 & 0.07 & 0.43 \\
\hline $\mathrm{FeO}$ & 0.05 & 0.11 & 0.07 & 0.14 & 0.12 & 0.06 & 0.92 \\
\hline Total & 98.10 & 98.98 & 99.57 & 99.86 & 99.46 & 99.90 & 98.40 \\
\hline \multicolumn{8}{|c|}{ Cation on 8 Oxygen } \\
\hline $\mathrm{Si}$ & 2.550 & 2.532 & 2.594 & 2.595 & 2.551 & 2.602 & 3.096 \\
\hline $\mathrm{Al}$ & 1.458 & 1.466 & 1.378 & 1.384 & 1.423 & 1.377 & 2.582 \\
\hline $\mathrm{Fe}$ & 0.000 & 0.004 & 0.002 & 0.005 & 0.004 & 0.002 & 0.056 \\
\hline$\sum \mathrm{Z}$ & 4.008 & 4.002 & 3.978 & 3.984 & 3.978 & 3.98 & 5.734 \\
\hline $\mathrm{Ca}$ & 0.426 & 0.451 & 0.438 & 0.434 & 0.473 & 0.418 & 1.681 \\
\hline K & 0.003 & 0.003 & 0.004 & 0.003 & 0.003 & 0.004 & 0.040 \\
\hline $\mathrm{Na}$ & 0.565 & 0.448 & 0.599 & 0.588 & 0.568 & 0.613 & 0.355 \\
\hline$\sum X$ & 0.994 & 0.902 & 1.041 & 1.025 & 1.044 & 1.04 & 2.076 \\
\hline An & 0.428 & 0.500 & 0.421 & 0.423 & 0.453 & 0.41 & 0.810 \\
\hline
\end{tabular}

Table 2(b). EPMA data of biotite.

\begin{tabular}{|c|c|c|c|c|c|c|c|}
\hline \multirow[t]{3}{*}{ Rock type } & \multicolumn{5}{|c|}{ Metapelites } & \multicolumn{2}{|c|}{ Metabasites } \\
\hline & $\overline{\mathrm{M} 232}$ & M232 & M232 & M34/C4 & $\mathrm{M} 34 / \mathrm{C} 1$ & M38 & M38 \\
\hline & $\mathrm{C} 1 / 2$ & $\mathrm{C} 1 / 4$ & $\mathrm{C} 4 / 2$ & $\mathrm{C} 4$ & $\mathrm{C} 1$ & $\mathrm{C} 1$ & $\mathrm{C} 4$ \\
\hline Sample & Core & Rim & Isolated & Rim & Core & & \\
\hline $\mathrm{SiO}_{2}$ & 37.72 & 39.20 & 38.94 & 34.48 & 35.85 & 34.09 & 35.18 \\
\hline $\mathrm{Al}_{2} \mathrm{O}_{3}$ & 17.33 & 18.06 & 17.67 & 15.98 & 16.40 & 16.30 & 15.95 \\
\hline $\mathrm{FeO}$ & 18.93 & 18.49 & 19.01 & 26.06 & 25.06 & 25.35 & 24.89 \\
\hline $\mathrm{MgO}$ & 11.84 & 11.64 & 11.61 & 7.33 & 7.61 & 8.53 & 7.35 \\
\hline $\mathrm{MnO}$ & 0.01 & 0.03 & 0.01 & 0.06 & 0.04 & 0.08 & 0.08 \\
\hline $\mathrm{CaO}$ & 0.01 & 0.06 & 0.07 & & 0.09 & 0.08 & 0.05 \\
\hline $\mathrm{K}_{2} \mathrm{O}$ & 8.60 & 6.26 & 7.54 & 9.55 & 9.16 & 8.05 & 9.01 \\
\hline $\mathrm{Na} 2 \mathrm{O}$ & 0.39 & 0.18 & 0.23 & 0.02 & 0.17 & 0.14 & 0.07 \\
\hline $\mathrm{TiO} 2$ & 1.40 & 1.37 & 1.36 & 1.35 & 1.71 & 1.52 & 1.25 \\
\hline $\mathrm{Cr}_{2} \mathrm{O}_{3}$ & 0.03 & 0.01 & & & 0.02 & 0.01 & \\
\hline Total & 96.26 & 95.30 & 96.44 & 94.83 & 96.11 & 94.15 & 93.83 \\
\hline \multicolumn{8}{|c|}{ Cation on 22 Oxygen } \\
\hline $\mathrm{Si}$ & 5.623 & 5.770 & 5.730 & 5.492 & 5.565 & 5.411 & 5.602 \\
\hline $\mathrm{Al}^{\mathrm{IV}}$ & 2.377 & 2.230 & 2.270 & 2.508 & 2.435 & 2.589 & 2.398 \\
\hline$\sum \mathrm{Z}$ & 8.000 & 8.000 & 8.000 & 8.000 & 8.000 & 8.000 & 8.000 \\
\hline $\mathrm{Al}^{\mathrm{VI}}$ & 0.669 & 0.904 & 0.796 & 0.491 & 0.566 & 0.460 & 0.596 \\
\hline $\mathrm{Ti}$ & 0.156 & 0.152 & 0.151 & 0.161 & 0.200 & 0.181 & 0.015 \\
\hline $\mathrm{Cr}$ & 0.003 & 0.003 & 0.000 & 0.000 & 0.002 & 0.001 & 0.000 \\
\hline $\mathrm{Fe}$ & 2.360 & 2.276 & 2.340 & 3.471 & 3.253 & 3.364 & 3.315 \\
\hline $\mathrm{Mg}$ & 2.631 & 2.554 & 2.546 & 1.740 & 1.761 & 2.018 & 1.745 \\
\hline Mn & 0.002 & 0.004 & 0.002 & 0.008 & 0.006 & 0.010 & 0.100 \\
\hline$\sum \mathrm{X}$ & 5.821 & 5.893 & 5.835 & 5.871 & 5.788 & 6.034 & 5.767 \\
\hline K & 1.636 & 1.175 & 1.415 & 1.941 & 1.813 & 1.629 & 1.831 \\
\hline $\mathrm{Ca}$ & 0.001 & 0.001 & 0.011 & 0.000 & 0.015 & 0.013 & 0.009 \\
\hline $\mathrm{Na}$ & 0.114 & 0.050 & 0.065 & 0.007 & 0.051 & 0.042 & 0.020 \\
\hline$\sum \mathrm{Y}$ & 1.751 & 1.226 & 1.491 & 1.948 & 1.879 & 1.674 & 1.860 \\
\hline $\mathrm{X}_{\mathrm{Mg}}$ & 0.527 & 0.528 & 0.521 & 0.334 & 0.351 & 0.375 & 0.345 \\
\hline
\end{tabular}


Table 2(c). EPMA data of cordierite.

\begin{tabular}{|c|c|c|}
\hline \multirow{3}{*}{$\begin{array}{l}\text { Rock type } \\
\text { Sample no. }\end{array}$} & \multicolumn{2}{|c|}{ Metapelites } \\
\hline & $\overline{\mathrm{M} 232 / \mathrm{C} 1}$ & $\mathrm{M} 232 / \mathrm{C} 4$ \\
\hline & $\operatorname{Rim}$ & Core \\
\hline $\mathrm{SiO}_{2}$ & 50.05 & 48.91 \\
\hline $\mathrm{Al}_{2} \mathrm{O}_{3}$ & 31.91 & 31.38 \\
\hline $\mathrm{FeO}$ & 7.35 & 7.84 \\
\hline $\mathrm{MgO}$ & 7.62 & 8.19 \\
\hline $\mathrm{MnO}$ & 0.09 & 0.13 \\
\hline $\mathrm{Na}_{2} \mathrm{O}$ & 1.01 & 0.32 \\
\hline Total & 98.03 & 96.77 \\
\hline \multicolumn{3}{|c|}{ Cation on 18 Oxygen } \\
\hline $\mathrm{Si}$ & 5.146 & 5.104 \\
\hline $\mathrm{Al}$ & 3.867 & 3.860 \\
\hline$\sum \mathrm{Z}$ & 9.013 & 8.964 \\
\hline $\mathrm{Fe}$ & 0.632 & 0.689 \\
\hline $\mathrm{Mg}$ & 1.168 & 1.274 \\
\hline Mn & 0.007 & 0.012 \\
\hline$\sum \mathrm{X}$ & 1.807 & 1.975 \\
\hline $\mathrm{Na}$ & 0.200 & 0.064 \\
\hline $\mathrm{X}_{\mathrm{Mg}}$ & 0.649 & 0.646 \\
\hline $\mathrm{aCrd}$ & 0.467 & 0.437 \\
\hline afCrd & 0.133 & 0.143 \\
\hline
\end{tabular}

\subsection{Amphibole}

The calcic amphibole is present in these rocks, in which $\mathrm{Al}_{2} \mathrm{O}_{3}$ ranges from 11.43 to $17.20 \mathrm{wt} \%$ (table 2d). The $\mathrm{MnO}$ is always less than $0.5 \mathrm{wt} \%$. The $\mathrm{X}_{\mathrm{Mg}}$ ranges from 0.245 to 0.290 . The $\mathrm{Al}^{\mathrm{IV}}$ and $\mathrm{Al}^{\mathrm{VI}}$ content of hornblende rages from 1.385 to 1.795 and 0.715 to $1.318 \mathrm{pfu}$, respectively. The $\mathrm{Ti}$ content of hornblende varies between 0.025 and $0.1 \mathrm{pfu}$ and wt\% of $\mathrm{TiO}_{2}$ varies from 0.22 to 0.85 .

\section{5. $\mathbf{P}-\mathbf{T}$ conditions of metamorphism and $\mathbf{P}-\mathbf{T}$ path}

The pressure and temperature conditions of metamorphism of the garnet-cordierite-sillimanite gneiss, garnet-sillimanite-biotite gneiss, garnetbiotite gneiss and garnet-hornblende-biotite gneiss have been estimated by $\mathrm{Fe}-\mathrm{Mg}$ garnet-cordierite and garnet-biotite geothermometry and garnetbiotite-sillimanite-K-feldspar-quartz geobarometry. In addition, sets of independent reactions between mineral end-members were calculated by THERMOCALC v3.1 (Powell and Holland 1988) using the internally consistent dataset of Holland and Powell (1998), and the internally consistent geothermobarometry of Dwivedi et al. (1997). The temperature estimates for garnet-cordieritesillimanite gneiss from the various conventional Grt-Bt geothermometers (table 3) range between $860^{\circ}$ and $722^{\circ} \mathrm{C}$ for the core and between $680^{\circ}$ and $610^{\circ} \mathrm{C}$ for rim compositions of garnet. The
Table 2(d). EPMA data of amphibole.

\begin{tabular}{|c|c|c|c|}
\hline \multirow{2}{*}{$\begin{array}{l}\text { Rock type } \\
\text { Sample no. }\end{array}$} & \multicolumn{3}{|c|}{ Metabasites } \\
\hline & $\mathrm{M} 35 / \mathrm{c} 1 / 1$ & $\mathrm{M} 35 / \mathrm{c} 3 / 3$ & $\mathrm{M} 35 / \mathrm{c} 5 / 4$ \\
\hline $\mathrm{SiO}_{2}$ & 42.44 & 41.60 & 40.59 \\
\hline $\mathrm{Al}_{2} \mathrm{O}_{3}$ & 11.43 & 15.88 & 17.20 \\
\hline $\mathrm{FeO}$ & 24.87 & 21.23 & 22.33 \\
\hline $\mathrm{MgO}$ & 5.71 & 4.78 & 4.07 \\
\hline $\mathrm{MnO}$ & 0.27 & 0.20 & 0.28 \\
\hline $\mathrm{CaO}$ & 9.77 & 11.35 & 11.42 \\
\hline $\mathrm{K}_{2} \mathrm{O}$ & 0.28 & 0.26 & 0.15 \\
\hline $\mathrm{Na}_{2} \mathrm{O}$ & 1.00 & 1.11 & 1.23 \\
\hline $\mathrm{TiO}_{2}$ & 0.85 & 0.22 & 0.04 \\
\hline $\mathrm{Cr}_{2} \mathrm{O}_{3}$ & & 0.02 & 0.03 \\
\hline $\mathrm{ZnO}$ & 0.04 & 0.05 & 0.06 \\
\hline Total & 96.66 & 96.70 & 97.40 \\
\hline \multicolumn{4}{|c|}{ Cation on 23 Oxygen } \\
\hline $\mathrm{Si}$ & 6.615 & 6.348 & 6.215 \\
\hline $\mathrm{Al}^{\mathrm{iv}}$ & 1.385 & 1.652 & 1.795 \\
\hline$\sum \mathrm{Z}$ & 8.000 & 8.000 & 8.000 \\
\hline $\mathrm{Al}^{\mathrm{vi}}$ & 0.715 & 1.205 & 1.318 \\
\hline $\mathrm{Fe}$ & 3.242 & 2.756 & 2.859 \\
\hline $\mathrm{Mg}$ & 1.327 & 1.087 & 0.928 \\
\hline $\mathrm{Mn}$ & 0.035 & 0.026 & 0.036 \\
\hline $\mathrm{Ti}$ & 0.100 & 0.025 & 0.048 \\
\hline $\mathrm{Cr}$ & 0.000 & 0.002 & 0.004 \\
\hline $\mathrm{Zn}$ & 0.005 & 0.005 & 0.006 \\
\hline$\sum \mathrm{X}$ & 5.424 & 5.106 & 5.199 \\
\hline $\mathrm{Ca}$ & 1.632 & 1.856 & 1.873 \\
\hline $\mathrm{Na}$ & 0.301 & 0.328 & 0.365 \\
\hline K & 0.056 & 0.051 & 0.029 \\
\hline$\sum Y$ & 1.989 & 2.235 & 2.267 \\
\hline$\sum \mathrm{X}+\sum \mathrm{Y}$ & 7.413 & 7.340 & 7.466 \\
\hline $\mathrm{X}_{\mathrm{Mg}}$ & 0.290 & 0.284 & 0.245 \\
\hline
\end{tabular}

variation in the temperature estimates is mainly due to limitation of geothermometers and mixing models of garnet and biotite incorporated for formulation of geothermometers. The temperature obtained by these geothermometers for garnet-sillimanite-biotite-gneiss ranges from $727^{\circ}$ to $632^{\circ} \mathrm{C}$ for core and $700^{\circ}$ to $633^{\circ} \mathrm{C}$ for rim. The garnetiferous amphibolite temperature obtained from Grt-Bt geothermometry ranges between $735^{\circ}$ to $660^{\circ} \mathrm{C}$ and is lower in comparison to the pelitic rocks. The garnet-hornblende-biotite gneiss temperature estimate is always lower than pelitic gniess and varies from $650^{\circ}$ to $549^{\circ} \mathrm{C}$ (garnet core) and $641^{\circ}$ to $551^{\circ} \mathrm{C}$ (garnet rim) that may be due to retrogression. The temperature obtained from garnet-cordierite-sillimanite gneiss using various calibrations of the Grt-Crd geothermometers (table 3) ranges between $711^{\circ}$ and $631^{\circ} \mathrm{C}$ for the garnet core and between $694^{\circ}$ and $603^{\circ} \mathrm{C}$ for the garnet rim. The average temperature estimate obtained from garnet-cordierite-sillimanite- 
Table 2(e). EPMA data of garnet.

\begin{tabular}{|c|c|c|c|c|c|c|c|c|c|c|c|c|}
\hline \multirow{2}{*}{$\begin{array}{l}\text { Rock type } \\
\text { Sample } \\
\text { no. }\end{array}$} & \multicolumn{8}{|c|}{ Metapelites } & \multicolumn{4}{|c|}{ Metabasites } \\
\hline & $\begin{array}{l}\text { M232 } \\
\text { C1/2 } \\
\text { Core }\end{array}$ & $\begin{array}{l}\text { M232/ } \\
\text { C1/4 } \\
\text { Core }\end{array}$ & $\begin{array}{l}\text { M232 } \\
/ \text { C4/1 } \\
\text { Rim }\end{array}$ & $\begin{array}{l}\text { M232/ } \\
\text { C4/4 } \\
\text { Rim }\end{array}$ & $\begin{array}{l}\text { M34/ } \\
\text { C1/1 } \\
\text { Core }\end{array}$ & $\begin{array}{l}\text { M 34- } \\
\text { C1/2 } \\
\text { Rim }\end{array}$ & $\begin{array}{l}\text { M34- } \\
\text { C4/2 } \\
\text { Rim }\end{array}$ & $\begin{array}{l}\text { M34- } \\
\text { C4/3 } \\
\text { Core }\end{array}$ & $\begin{array}{l}\text { M35/C1 } \\
\operatorname{Rim}\end{array}$ & $\begin{array}{l}\text { M35/C5 } \\
\text { Core }\end{array}$ & $\begin{array}{l}\mathrm{M} / 38 / \mathrm{C} 1 \\
\text { Core }\end{array}$ & $\begin{array}{l}\mathrm{M} 38 / \mathrm{C} 4 \\
\operatorname{Rim}\end{array}$ \\
\hline $\mathrm{SiO}_{2}$ & 37.77 & 37.93 & 37.54 & 37.39 & 37.54 & 37.41 & 37.19 & 37.03 & 37.33 & 37.30 & 37.96 & 37.11 \\
\hline $\mathrm{Al}_{2} \mathrm{O}_{3}$ & 21.11 & 21.52 & 21.02 & 20.99 & 20.35 & 20.68 & 20.63 & 20.71 & 20.52 & 19.91 & 20.54 & 20.33 \\
\hline $\mathrm{FeO}$ & 33.58 & 31.39 & 33.80 & 34.25 & 29.99 & 27.34 & 29.61 & 31.90 & 28.62 & 29.64 & 31.39 & 31.13 \\
\hline $\mathrm{MgO}$ & 4.17 & 6.56 & 3.91 & 3.65 & 2.00 & 1.56 & 1.36 & 1.85 & 1.33 & 1.94 & 1.60 & 1.50 \\
\hline $\mathrm{MnO}$ & 1.62 & 0.82 & 1.77 & 1.72 & 2.36 & 3.48 & 2.73 & 2.15 & 3.17 & 1.91 & 3.28 & 3.13 \\
\hline $\mathrm{CaO}$ & 2.26 & 2.19 & 2.01 & 2.04 & 7.62 & 8.78 & 7.82 & 5.98 & 8.39 & 7.56 & 5.78 & 6.13 \\
\hline $\mathrm{TiO}_{2}$ & 0.01 & 0.12 & 0.01 & 0.03 & 0.04 & 0.02 & 0.04 & 0.04 & 0.05 & 0.03 & 0.05 & 0.04 \\
\hline $\mathrm{Cr}_{2} \mathrm{O}_{3}$ & 0.00 & 0.02 & 0.00 & 0.02 & 0.00 & 0.00 & 0.05 & 0.00 & 0.00 & 0.01 & 0.01 & 0.00 \\
\hline $\mathrm{NiO}$ & 0.00 & 0.01 & 0.00 & 0.02 & 0.04 & 0.01 & 0.01 & 0.00 & 0.00 & 0.01 & 0.00 & 0.00 \\
\hline $\mathrm{ZnO}$ & 0.00 & 0.02 & 0.01 & 0.00 & 0.00 & 0.00 & 0.00 & 0.01 & 0.04 & 0.03 & 0.00 & 0.03 \\
\hline Total & 100.52 & 100.58 & 100.07 & 100.11 & 99.94 & 99.28 & 99.44 & 99.67 & 99.45 & 98.34 & 100.61 & 99.40 \\
\hline \multicolumn{13}{|c|}{ Cation on 12 Oxygen } \\
\hline $\mathrm{Si}$ & 3.041 & 3.001 & 3.042 & 3.036 & 3.055 & 3.053 & 3.046 & 3.034 & 3.053 & 3.039 & 3.078 & 3.054 \\
\hline $\mathrm{Al}$ & 1.952 & 1.961 & 1.956 & 1.957 & 1.902 & 1.937 & 1.939 & 1.948 & 1.927 & 1.912 & 1.912 & 1.920 \\
\hline $\mathrm{Ti}$ & 0.001 & 0.007 & 0.001 & 0.002 & 0.002 & 0.001 & 0.002 & 0.002 & 0.002 & 0.002 & 0.003 & 0.003 \\
\hline $\mathrm{Cr}$ & 0.000 & 0.001 & 0.000 & 0.001 & 0.000 & 0.000 & 0.003 & 0.000 & 0.000 & 0.001 & 0.001 & 0.000 \\
\hline $\mathrm{Fe}$ & 2.203 & 2.030 & 2.232 & 2.266 & 1.989 & 1.818 & 1.975 & 2.128 & 1.907 & 2.019 & 2.073 & 2.086 \\
\hline $\mathrm{Mg}$ & 0.488 & 0.756 & 0.460 & 0.431 & 0.236 & 0.185 & 0.162 & 0.220 & 0.158 & 0.235 & 0.189 & 0.179 \\
\hline $\mathrm{Mn}$ & 0.107 & 0.054 & 0.118 & 0.115 & 0.159 & 0.234 & 0.185 & 0.145 & 0.214 & 0.132 & 0.219 & 0.213 \\
\hline $\mathrm{Ca}$ & 0.190 & 0.181 & 0.170 & 0.173 & 0.647 & 0.748 & 0.668 & 0.512 & 0.716 & 0.660 & 0.489 & 0.527 \\
\hline $\mathrm{Zn}$ & 0.000 & 0.001 & 0.001 & 0.000 & 0.000 & 0.000 & 0.000 & 0.001 & 0.002 & 0.002 & 0.000 & 0.002 \\
\hline $\mathrm{Ni}$ & 0.000 & 0.000 & 0.000 & 0.001 & 0.002 & 0.000 & 0.000 & 0.000 & 0.000 & 0.001 & 0.000 & 0.000 \\
\hline Prp & 16.33 & 25.02 & 15.43 & 14.43 & 7.78 & 6.19 & 5.41 & 7.33 & 5.28 & 7.72 & 6.35 & 5.96 \\
\hline Alm & 73.72 & 67.20 & 74.89 & 75.92 & 65.63 & 60.90 & 66.07 & 70.81 & 63.67 & 66.28 & 69.80 & 69.42 \\
\hline Sps & 3.58 & 1.78 & 3.97 & 3.87 & 5.23 & 7.85 & 6.17 & 4.83 & 7.14 & 4.33 & 7.37 & 7.09 \\
\hline Grs & 6.35 & 6.00 & 5.72 & 5.78 & 21.35 & 25.05 & 22.35 & 17.02 & 23.91 & 21.66 & 16.46 & 17.54 \\
\hline
\end{tabular}

biotite gneiss ranges between $773 \pm 41^{\circ}$ and $675 \pm$ $31^{\circ} \mathrm{C}$ from Grt-Bt and Grt-Crd geothermometers for the assemblages Grt-Bt-Sill-Plag-kfs-Qz and Grt-Crd-Sill-kfs-Qz respectively. However, some temperature estimates are exceptionally high between $790^{\circ}$ and $860^{\circ} \mathrm{C}$ using garnet-biotite pair (Thompson 1976; Ferry and Spear 1978; Aranovich et al. 1988), which possibly imply lack of equilibrium between the two phases at places.

Pressure estimates for garnet-cordieritesillimanite gneiss vary between $3.05-5.88 \mathrm{kbar}$ ( $\mathrm{Fe}$ end member reaction) and 4.44-6.59 kbar ( $\mathrm{Mg}$ end member reaction) using garnet-cordieritesillimanite-quartz geobarometer, while the pressure estimates for garnet-hornblende gneiss and garnet amphibolites ranges between 3.9-4.0 kbar and 5.4-4.3 kbar respectively using garnet-biotiteK-feldspar-quartz geobarometer (table 3). The model of Koziol and Newton (1988) geobaromerter estimates low pressure $\sim 4.5$ kbar for the garnetplagioclase-sillimanite-quartz bearing assemblage of pelitic rock. $\mathrm{P}-\mathrm{T}$ estimates of garnet-cordieritesillimanite gneiss from the internally consistent geothermobarometry and internally consistent dataset range between $720^{\circ} \mathrm{C} / 6.2$ kbar and $687^{\circ} \mathrm{C} / 4.9 \mathrm{kbar}$ for the assemblages Grt-Crd-Sill$\mathrm{Kfs}-\mathrm{Qz}$ using the core composition of garnet. The mafic gneisses (garnet-hornblende-biotite gneiss and garnetiferous amphibolites) based on the independent set of mineral end-member reactions (given as Appendix) also records low estimates of $\mathrm{P}-\mathrm{T}$ ranges by the internally consistent geothermobarometry and ranges from $579^{\circ} \mathrm{C} / 4.4$ to $545^{\circ} \mathrm{C} / 4.3 \mathrm{kbar}$.

Based on textural relations between coexisting mineral phases and geothermobarometry estimates from garnet-cordierite-sillimanite gneiss, a $\mathrm{P}-\mathrm{T}$ path has been constructed. The assemblage garnet-cordierite-sillimanite \pm biotite$\mathrm{K}$-feldspar-quartz appears in the pelitic gneisses at $\sim 720^{\circ} \mathrm{C} / 6.2 \mathrm{kbar}$ and is followed by retrograde evolution at $687^{\circ} \mathrm{C} / 4.9 \mathrm{kbar}$, indicating a retrograde cooling path (figure 5 ). The internally consistent geothermobaromerty estimates for mafic rocks ranges between $579^{\circ} \mathrm{C} / 4.4$ and $545^{\circ} \mathrm{C} / 4.3 \mathrm{kbar}$ may be accorded to the $\mathrm{P}-\mathrm{T}$ retrograde trajectory 
Table 3. Estimates of P-T conditions of metamorphism of pelitic and mafic rocks of BnGC from Mauranipur area, Bundelkhand Craton.

\begin{tabular}{|c|c|c|c|c|c|c|c|c|c|}
\hline \multirow{5}{*}{ Sample no. } & \multicolumn{6}{|c|}{ Metapelites } & \multicolumn{3}{|c|}{ Metabasites } \\
\hline & \multicolumn{4}{|c|}{$\begin{array}{l}\text { Garnet-cordierite-sillimanite } \\
\text { gneissses }\end{array}$} & \multirow{3}{*}{\multicolumn{2}{|c|}{$\begin{array}{c}\begin{array}{c}\text { Garnet-sillmanite-biotite } \\
\text { gneisses }\end{array} \\
\text { Grt-Bt } \\
\text { geothermometers } \\
\text { M34 }\end{array}$}} & \multirow{4}{*}{$\begin{array}{l}\text { Garnetiferous } \\
\text { amphibolite } \\
\text { M35 } \\
\text { Core }\end{array}$} & \multirow{2}{*}{\multicolumn{2}{|c|}{$\begin{array}{c}\text { Hornblende-biotite } \\
\text { gneisses } \\
\text { Grt-Bt } \\
\text { geothermometers }\end{array}$}} \\
\hline & \multirow{2}{*}{\multicolumn{2}{|c|}{$\begin{array}{c}\begin{array}{c}\text { Grt-Crd } \\
\text { geothermometers }\end{array} \\
\text { M232 }\end{array}$}} & \multirow{2}{*}{\multicolumn{2}{|c|}{$\begin{array}{c}\begin{array}{c}\text { Grt-Bt } \\
\text { geothermometers }\end{array} \\
\text { M232 }\end{array}$}} & & & & & \\
\hline & & & & & & & & M38 & M38 \\
\hline & Core & Rim & Core & $\operatorname{Rim}$ & Core & $\operatorname{Rim}$ & & Core & Rim \\
\hline A & 655 & 632 & 800 & 626 & 655 & 638 & 685 & 573 & 556 \\
\hline B & 644 & 623 & 860 & 618 & 656 & 633 & 697 & 549 & 528 \\
\hline $\mathrm{C}$ & 710 & 694 & 722 & 643 & 707 & 672 & 735 & 616 & 610 \\
\hline $\mathrm{D}$ & 658 & 635 & 775 & 610 & 671 & 636 & 634 & 577 & 558 \\
\hline $\mathrm{E}$ & 688 & 663 & 790 & 669 & 727 & 700 & 682 & 650 & 641 \\
\hline $\mathrm{F}$ & 631 & 603 & 740 & 627 & 640 & 620 & 679 & 562 & 551 \\
\hline G & 711 & 688 & 759 & 635 & 632 & 635 & 661 & 562 & 562 \\
\hline $\mathrm{H}$ & 710 & 689 & 738 & 680 & 635 & 645 & 660 & 580 & 568 \\
\hline Average $\mathrm{T}\left({ }^{\circ} \mathrm{C}\right)$ & $675 \pm 31$ & $653 \pm 33$ & $773 \pm 41$ & $638 \pm 23$ & $665 \pm 32$ & $647 \pm 24$ & $679 \pm 28$ & $583 \pm 31$ & $571 \pm 34$ \\
\hline \multicolumn{10}{|c|}{ Garnet-biotite-K-feldspar-quartz geobarometer (Wu et al. 2004) } \\
\hline & 5.4 & 5.1 & & & 5.1 & 5.3 & 4.3 & 3.9 & 4.0 \\
\hline \multicolumn{9}{|c|}{ Garnet-cordierite-sillimanite-quartz geobarometer } & \\
\hline $\mathrm{a}$ & 6.59 & 5.88 & & & & & & & \\
\hline $\mathrm{b}$ & 6.06 & 5.62 & & & & & & & \\
\hline $\mathrm{c}$ & 4.44 & & & & & & & & \\
\hline d & 4.67 & 3.05 & & & & & & & \\
\hline Average $\mathrm{P}$ (kbar) & $5.44 \pm 1$ & $4.85 \pm 0.8$ & & & & & & & \\
\hline \multicolumn{10}{|c|}{ Result of internally consistent geothermobarometry } \\
\hline $\mathrm{X}$ & & & $720^{\circ} \mathrm{C}$ & $6.2 \mathrm{kbar}$ & & & $579^{\circ} \mathrm{C} / 4.4 \mathrm{kbar}$ & $545^{\circ} \mathrm{C}$ & / $/ 4.3 \mathrm{kbar}$ \\
\hline $\mathrm{Y}$ & & & $687^{\circ} \mathrm{C}$ & /4.9 kbar & & & & & \\
\hline
\end{tabular}

where Grt-Bt, A=Thompson (1976), B=Ferry and Spear (1978), C=Perchuk et al. (1985), D=Dasgupta et al. (1991), $\mathrm{E}=$ Aranovich et al. (1988), $\mathrm{F}=$ Bhattacharya et al. (1992a), $\mathrm{G}=$ Holdaway (2000), $\mathrm{H}=\mathrm{Dwivedi}$ et al. (2007); In Grt-Crd, $\mathrm{A}=$ Thompson (1976), B=Perchuk et al. (1985), $\mathrm{C}=$ Bhattacharya et al. (1992b), $\mathrm{D}=$ Perchuk (1991), $\mathrm{E}=\mathrm{Aranovich}$ and Podlesskii (1983), $\mathrm{F}=$ Nichols et al. (1992) $\mathrm{G}=$ Dwivedi (1996), $\mathrm{H}=$ Dwivedi et al. (1998); In Grt-crd-sill geobarometer, $\mathrm{a}=$ Thompson (1976), b=Wells (1979), c=Perchuk et al. (1985), d=Aranovich and Podlesskii (1983) ; X=Thermocalc Win 2007, Y=Dwivedi et al. (1997).

proposed for pelitic rocks. The estimates of temperature from $665 \pm 32^{\circ} \mathrm{C}$ (core) to $647 \pm 24^{\circ} \mathrm{C}$ (rim) of garnet-sillimanite-biotite gneiss and $583 \pm 31^{\circ} \mathrm{C}$ (core) to $571 \pm 34^{\circ} \mathrm{C}$ (rim) of garnet-hornblendebiotite gneiss (table 3) could be a possible segment of proposed cooling path with high brackets or may be an independent window.

\section{Discussion}

Geochronological data of TTG rocks of Mauranipur (Kuraicha) indicates $3297 \pm 8 \mathrm{Ma}$ (Mondal et al. 2002) age of crystallization which is more or less contemporaneous with the TTGs of Bundelkhand massif exposed at other places (Mondal 2010; Saha et al. 2011; Kumar et al. 2011). Medium pressure granulite facies metamorphic conditions of $6.2 \mathrm{kbar}$ and temperature estimates between $773^{\circ}$ and $720^{\circ} \mathrm{C}$ from pelitic rocks of Mauranipur area is very much comparable to several high-grade Mesoarchean metamorphic rock (Peucat et al. 1993; Diener et al. 2005; Brown 2006; Moyen et al. 2006; Lana et al. 2010) from several cratons in the time and space. The pelitic and quartzofelspathic rock sequences exposed at Mauranipur (figure 2) appear as the oldest supracrustal rock sequences that have been deformed and metamorphosed into granulite facies condition. Textural study, mineral assemblages, pressure and temperature estimates calculated from the pelitic gneisses, garnetiferous amphibolite and garnet-hornblende-biotite gneiss of Mauranipur preserve prograde and retrograde stages of metamorphism. The prograde metamorphic history is very fragmentary and is mainly characterized by the association GrtBt-Sill-Kfs-Plag-Qz. The thermal peak stage is related to the granulite facies condition and is defined by the garnet core temperature of $773^{\circ} \mathrm{C} \pm$ $41^{\circ} \mathrm{C} / 5.4 \pm 1 \mathrm{kbar}$ for thermal peak assemblages 


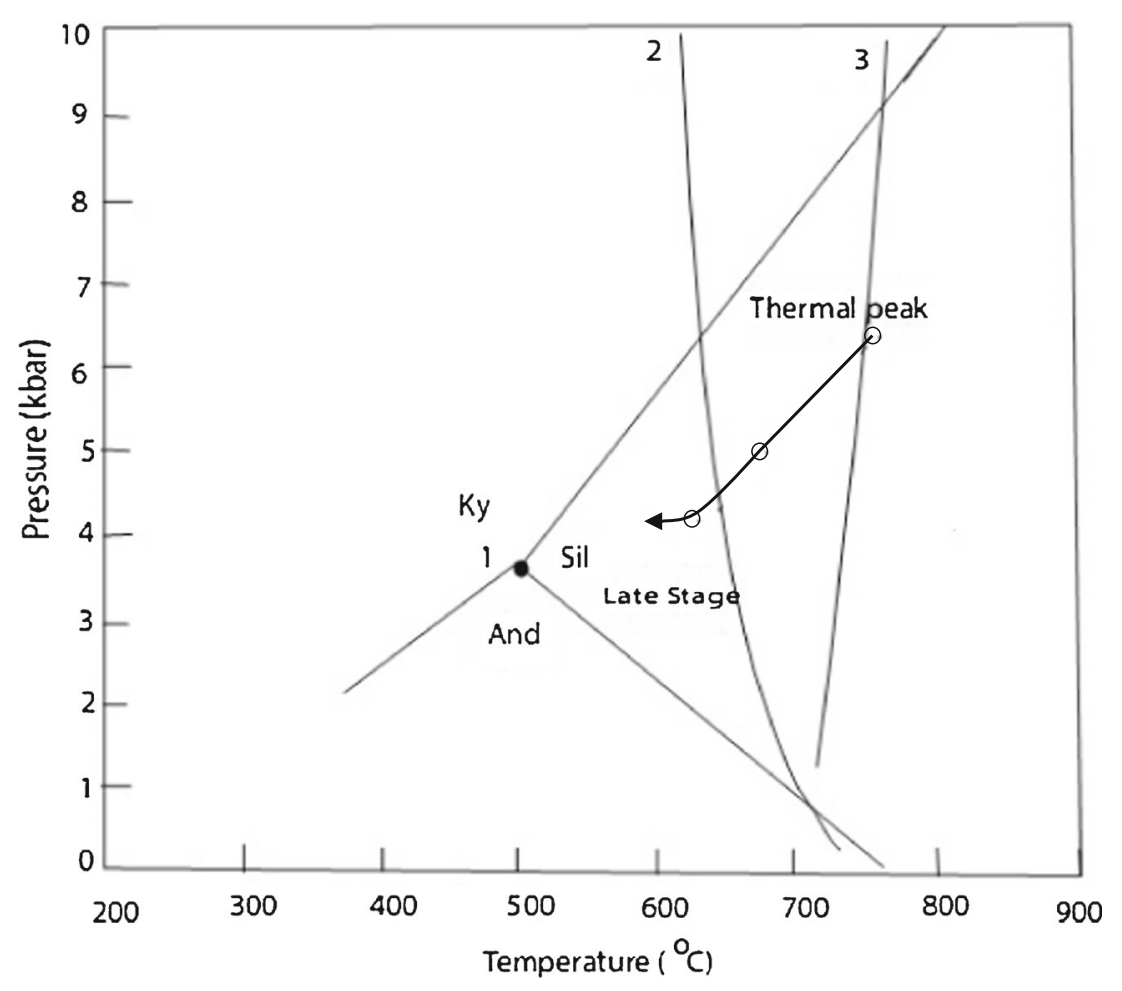

Figure 5. $\mathrm{P}-\mathrm{T}$ path of the gneisses of Mauranipur in Bundelkhand Craton showing evolution of retrograde stages of metamorphism, where (1) triple point of Holdaway (1971), (2) $\mathrm{H}_{2} \mathrm{O}$-saturated pelite solidus (Thompson 1982) and (3) biotite + aluminosilicate + plagioclase + quartz $=$ garnet + K-feldspar + liquid (Le Breton and Thompson 1988).

Grt-Sil \pm Bt-Kfs-Plag-Qz. The growth of cordierite around garnet (figure $4 \mathrm{a}$ and $\mathrm{c}$ ) and appearance of assemblage Grt-Crd \pm Bt-Sil-Kfs-Qz at $720^{\circ} \mathrm{C} / 6.2 \mathrm{kbar}$ estimates the lower temperature due to retrograde metamorphism. The geothermobarometry deduced for these two distinct assemblages could not be precisely explained due to larger bracket of pressure and temperature estimates for core composition. The lower $\mathrm{P}-\mathrm{T}$ estimates of $679^{\circ} \mathrm{C} \pm 28^{\circ} \mathrm{C} / 4.3 \mathrm{kbar}$ in garnetiferous amphibolites, $665^{\circ} \mathrm{C} \pm 32^{\circ} \mathrm{C} / 5.1$ kbar ingarnet-sillimanite-biotite gneiss, and $583^{\circ} \mathrm{C}$ $\pm 31^{\circ} \mathrm{C} / 3.9 \mathrm{kbar}$ in garnet-hornblende-biotite gneiss (table 3) may appear to be a part of the segments of the same cooling path of late retrograde metamorphism at Mauranipur (figure 5).

Textural and field studies of the pelitic and mafic gneisses of Mauranipur show that these rocks have attained granulite facies metamorphic conditions. The drop in the pressure from 6.2 to $4.9 \mathrm{kbar}$ calculated from internally consistent geothemobarometry (table 3) suggest that the rocks underwent cooling with decompression (figure 5). The estimates of pressure at $\sim 6.2 \mathrm{kbar}$ for the pelitic gneisses of Mauranipur indicate that these rocks were situated at a depth of about $22 \mathrm{~km}$ $(3.5 \mathrm{~km} / \mathrm{kbar})$ at the metamorphic peak. If we consider present crustal thickness of the Bundelkhand as $\sim 35 \mathrm{~km}$ in the central zone (Gokarn et al. 2013;
Murthy et al. 2010), then crust thickness could be predicted as about $57 \mathrm{~km}$ at the time of thermal peak of the metamorphism. It is now generally accepted that regional granulite facies metamorphism require an input of extra heat which could be provided by the thickened crust. In order to get the thermal peak $\sim 773^{\circ} \mathrm{C}$ for the pelitic rocks, the total heat budget may be derived from upwelling of mantle magma or high geothermal gradient during Mesoarchean.

A discordant field relationship between TTG and gneisses (figure 3e) recorded from Mauranipur area points out that the undeformed TTG suite was emplaced later than the $\mathrm{D}_{2}$ event in gneisses. The geochronological data of $3297 \pm 8 \mathrm{Ma}$ of the TTG rocks of Mauranipur (Mondal et al. 2002) and the systematic isotope studies of TTG and pelitic gniesses (Mohan et al., in preparation) indicate that the metamorphism in gneisses possibly occurred during the Mesoarchean time and the high-grade pelitic rocks of Mauranipur are older than the emplacement of the TTG suite. The deduced $\mathrm{P}-\mathrm{T}$ trajectory of the lower crust of BnGC is the first direct evidence of the earliest event of crustal evolution. Thus occurrences of cooling signatures in metapelite rocks of granulite facies along the E-W trending crustal scale shear zones (Singh and Bhattacharya 2010) together constitute a system of very large scale structures in Bundelkhand Craton. 


\section{Conclusion}

The field relation, textural study, phase relationship, and metamorphic conditions based on geothermobarometry along with inputs of structural data reveal that BnGC rocks at Mauranipur area in the central part of Bundelkhand massif are definitely composite in nature, and metamorphosed under the granulite facies conditions.

\section{Acknowledgements}

SPS is thankful to the Ministry of Mines, Govt. of India, New Delhi and SBD is thankful to DST, Govt. of India for financial support. They are grateful to anonymous reviewers for the constructive review of the manuscript.

\section{Appendix}

The $\mathrm{P}-\mathrm{T}$ conditions of the garnet-hornblendebiotite gneisses is estimated by average $\mathrm{P}-\mathrm{T}$ calculation of THERMOCALC v.3.1 involving the independent set of reactions

(1) $2 \operatorname{Prp}+4 \mathrm{Grs}+3 \mathrm{Ts}+12 \mathrm{Qz}=3 \mathrm{Tr}+12 \mathrm{An}$,

(2) $3 \mathrm{Grs}+5 \mathrm{Ts}+11 \mathrm{Qz}=3 \mathrm{Tr}+13 \mathrm{An}+2 \mathrm{H}_{2} \mathrm{O}$,

(3) $6 \mathrm{Fac}+21 \mathrm{An}=11 \mathrm{Grs}+10 \mathrm{Alm}+27 \mathrm{Qz}+$ $6 \mathrm{H}_{2} \mathrm{O}$

(4) $3 \mathrm{Tr}+6$ Parg $+18 \mathrm{An}=4 \mathrm{Prp}+8 \mathrm{Grr}+6 \mathrm{Ts}+$ $3 \mathrm{Gln}$,

(5) $\operatorname{Prp}+2 \mathrm{Grs}+3 \mathrm{Eas}+6 \mathrm{Qz}=3 \mathrm{Phl}+6 \mathrm{An}$,

(6) $3 \mathrm{Eas}+3 \mathrm{Tr}+3 \mathrm{Parg}+9 \mathrm{Ab}=2 \mathrm{Prp}+4 \mathrm{Grs}+$ $3 \mathrm{Phl}+6 \mathrm{Gln}$,

(7) $3 \mathrm{Alm}+3 \mathrm{Eas}+3 \mathrm{Tr}+3 \mathrm{Parg}+9 \mathrm{Ab}=5 \operatorname{Prp}+$ $4 \mathrm{Grs}+3 \mathrm{Ann}+6 \mathrm{Gln}$.

The average $\mathrm{P}-\mathrm{T}$ obtained from the involved single end-member diagnostic information lie between $545 \pm 50^{\circ} \mathrm{C} / 4.3 \pm 1.1 \mathrm{kbar}$ and $579 \pm 56^{\circ} \mathrm{C} / 4.4 \pm$ $1.1 \mathrm{kbar}$ for sample nos. 35 and 38 (table 3 ).

\section{References}

Acharyya S K, Gupta A and Orihashi Y 2010 New U-Pb zircon ages from Paleo Mesoarchean TTG gneisses of the Singhbhum Craton, Eastern India; Geochem. J. 44 81-88.

Aranovich L Ya and Podlesskii K K 1983 The cordieritegarnet-sillimanite equilibrium: Experiments and application; In: Kinetics and Equilibrium in Mineral Reactions (ed.) Saxena S K (Berlin: Springer-Verlag), pp. 173-198.

Aranovich L Ya, Lavrent'eva I V and Kosyakova N A 1988 Biotite-garnet and biotite-orthopyroxene geothermometers: Calibrations accounting for the $\mathrm{Al}$ variations in biotite; Geokhim. 5 668-676.

Basu A K 1986 Geology of parts of the Bundelkhand granite massif, central India; Record Geol. Surv. India 117 61-124.
Basu A K 2010 Precambrian geology of the Bundelkhand terrain, central India and adjacent part of western India; J. Econ. Geol. Georesource Manag. 7 1-53.

Bhattacharya A R 1986 Wavelength-amplitude characteristics of polyphase folds in the Precambrian Bundelkhand Complex, India; Tectonophys. 128 121-125.

Bhattacharya A R and Singh S P 2013 Proterozoic crustal scale shearing in the Bundelkhand massif with special reference to Quartz Reefs; J. Geol. Soc. India $\mathbf{8 2}$ 474-484.

Bhattacharya A, Mazumdar A C and Sen S K 1992a Fe$\mathrm{Mg}$ mixing in cordierite: Constraints from natural data and implication for cordierite-garnet geothermometry in granulites; Am. Mineral. 73 338-344.

Bhattacharya A, Mohanty L, Maji A, Sen S K and Raith M 1992b Non-ideal mixing in the phlogopite-annite binary solution: Constraints from experimental data on $\mathrm{Mg}-\mathrm{Fe}$ partitioning and a reformulation of the biotitegarnet geothermometers; Contrib. Mineral. Petrol. 111 87-93.

Brown M 2006 Duality of thermal regims is the distinctive characteristic of plate tectonics since the Neoarchean; Geology 34 961-964.

Dasgupta S, Sengupta P, Guha D and Fukuoka M 1991 A refined garnet-biotite $\mathrm{Fe}-\mathrm{Mg}$ exchange geothermometer and its application in amphibolites and granulites; Contrib. Mineral. Petrol. 109 130-137.

Diener J F A, Stevens G, Kisters A F M and Poujol M 2005 Metamorphism and exhumation of the basal parts of the Barberton greenstone belt, South Africa: Constraining the rate of Mesoarchean tectonism; Precamb. Res. 143 87-112.

Dwivedi S B 1996 Non-ideal Mg-Fe binary mixing in cordierite: Constraints from experimental data on $\mathrm{Mg}-\mathrm{Fe}$ partitioning in garnet and cordierite and a reformulation of garnet-cordierite geothermometer; J. Earth Syst. Sci. $105365-377$.

Dwivedi S B, Mohan A and Lal R K 1997 Internally consistent geothermobarometers in the system $\mathrm{FeO}-\mathrm{MgO}-$ $\mathrm{Al}_{2} \mathrm{O}_{3}-\mathrm{SiO}_{2}-\mathrm{H}_{2} \mathrm{O}$ involving garnet, cordierite, aluminosilicate and quartz and their application to metapelites; J. Geol. Soc. India 49 647-669.

Dwivedi S B, Mohan A and Lal R K 1998 Recalibration of the $\mathrm{Fe}-\mathrm{Mg}$ exchange reaction between garnet and cordierite as a thermometer; Eur. J. Mineral. 10 281-289.

Dwivedi S B, Lalnunmawia J, Vanthangliana V and Lal S N 2007 A refined garnet-biotite thermometer: Constraints from empirically derived Margules parameters for garnet and biotite; The Indian Mineral. 41 97-111.

Ferry J M and Spear F S 1978 Experimental calibration of the partitioning of $\mathrm{Fe}$ and $\mathrm{Mg}$ between biotite and garnet; Contrib. Mineral. Petrol. 66 113-117.

Gokarn S G, Rao C K, Selvaraj C, Gupta G and Singh B P 2013 Crustal evolution and tectonics of the Archean Bundelkhand Craton, central India; J. Geol. Soc. India $82445-460$.

Holdaway M J 1971 Stability of andalusite and the aluminium silicate phase diagram; Am. J. Sci. 271 97131.

Holdaway M J 2000 Application of new experimental and garnet margules data to the garnet biotite geothermometer; Am. Mineral. 85 881-892.

Holland T J B and Powell R 1998 An internally-consistent thermodynamic dataset for phases of petrological interest; J. Meteor. Geol. 16 309-344.

Holland T J B and Powell R 2001 Calculation of phase relations involving haplogranite melts using an internally consistent data set; J. Petrol. 42 673-683.

Koziol A M and Newton R C 1988 Redetermination of the anorthite breakdown reaction and improvement of 
the plagioclase-garnet- $\mathrm{Al}_{2} \mathrm{SiO}_{5}$-quartz barometer; $\mathrm{Am}$. Mineral. 73 216-223.

Kumar S, Yi K, Raju K, Pathak M, Kim N and Lee T H 2011 SHRIMP U-Pb geochronology of felsic magmatic lithounits in the central part of Bundelkhand Craton, central India; In: 7th Hutton Symposium on Granites and Related Rocks, Avila, Spain (eds) Molina J F S, Bea F and Montero P, 83p.

Lana C, Kisters A and Stevens G 2010 Exhumation of Mesoarchean TTG gneisses from the middle crust: Insights from the Steynsdorp core complex, Barberton granitoid-greenstone terrain, South Africa; Bull. Geol. Soc. Am. 122 183-197.

Le Breton N and Thompson A B 1988 Fluid-absent (dehydration) melting of biotite in metapelites in the early stages of crustal anatexis; Contrib. Mineral. Petrol. 99 226-237.

Malviya V P, Arima M, Pati J K and Kuneko Y 2006 Petrology and geochemistry of basaltic pillow lava and basaltic komatiite in the Mauranipur area: Subductionrelated volcanism in the Archaean Bundelkhand Craton, central India; J. Mineral. Petrol. Sci. 101 199-217.

Mohan M R, Singh S P, Santosh M, Siddiqui M A and Balaram V 2012 TTG suite from the Bundelkhand Craton, central India: Geochemistry, petrogenesis and implications for Archean crustal evolution; J. Asian Earth Sci. 58 38-50.

Mondal M E A 2010 Geochemical evolution of the ArchaeanPaleoproterozoic Bundelkhand Craton, central Indian shield: Revisited; J. Econ. Geol. Georesour. Manag. 7 69-80.

Mondal M E A, Sharma K K, Rahman A and Goswami J N 1998 Ion microprobe ${ }^{207} \mathrm{~Pb} /{ }^{206} \mathrm{~Pb}$ zircon ages for the gneiss-granitoid rocks from Bundelkhand massif: Evidence for the Archaean components; Curr. Sci. 7470 75.

Mondal M E A, Goswami J N, Deomurari M P and Sharma K K 2002 Ion Microprobe ${ }^{207} \mathrm{~Pb} /{ }^{206} \mathrm{~Pb}$ ages of zircons from the Bundelkhand massif, northern India: Implications for crustal evolution of the Bundelkhand-Aravalli protocontinent; Precamb. Res. 117 95-110.

Moyen J F, Stevens G and Kisters A F M 2006 Record of mid-Archaean subduction from metamorphism in the Barberton terrain, South Africa; Nature 443 559-562.

Murthy A S N, Pandey O P and Sarkar D 2010 Seismic crustal structure of central India and an insight into geodynamic evolution of Bundelkhand Craton; J. Econ. Geol. Georesour. Manag. 7 91-107.

Nichols G T, Berry R F and Green D H 1992 Internally consistent granitic spinel-cordierite- garnet equilibrium in the FMASHZn system, geothermobarometry and application; Contrib. Mineral. Petrol. 111 362-373.

Pandey U K, Bhattacharya D, Sastry D V L N and Pandey B K 2011 Geochronology (Rb-Sr, Sm-Nd and Pb-Pb), isotope geochemisty and evolution of the granites and andesites hosting Mohar cauldron, Bundelkhand granite complex, Shivpuri district, central India; Explo. Res. Atom. Min. 21 103-116.

Perchuk L L 1991 Derivation of a thermodynamically consistent set of geothermometers and geobarometers for metamorphic and magmatic rocks; In: Progress in Metamorphic and Magmatic Petrology (ed.) Perchuk L L, Cambridge University Press, pp. 93-111.

Perchuk L L, Aranovich LYa, Podlesskii K K and Lavrenteva I V 1985 Precambrain granulites of the Alden Shield. Eastern Siberia USSR; J. Metamor. Geol. 3 265-310.

Peucat J J, Mahabaleswar B and Jayananda M 1993 Age of younger tonalitic magmatism and granulite metamorphism in the amphibolite-granulite transition zone of
Krishnagiri and comparison with the older gneisses from Gorur Hassan area; J. Metamor. Geol. 11 879-888.

Powell R and Holland T J B 1988 An internally consistent thermodynamic dataset with uncertaininties and correlations. III. Application methods, worked examples and a computer program; J. Metamor. Geol. 6 173-204.

Pradhan V R, Meerta J G, Pandit M K, Kamenova G and Mondal M E A 2012 Paleomagnetic and geochronological studies of the mafic dyke swarms of Bundelkhand Craton, central India: Implications for the tectonic evolution and paleogeographic reconstructions; Precamb. Res. 198-199 51-76.

Prasad M H, Hakim A and Rao B K 1999 Metavolcanic and metasedimentary inclusions in the Bundelkhand granitic complex in Tikamgarh district, Madhya Pradesh; J. Geol. Soc. India 54 359-368.

Rao M J, Rao G V S, Poornachandra Widdowson M and Kelley S P 2005 Evolution of Proterozoic mafic dyke swarms of the Bundelkhand Granite Massif, central India; Curr. Sci. 88 502-506.

Saha L, Hofmann A, Xie H, Hegner E, Wilson A, Wan Y, Liu D and Kröner A 2010 Zircon ages and metamorphic evolution of the Archaean Assegaai-De Kraalen granitoidgreenstone terrain, southeastern Kaapvaal Craton; Am. J. Sci. $3101384-1420$.

Saha L, Pant N C, Pati J K, Upadhyay D, Berndt J, Bhattacharya A and Satyanarayanan M 2011 Neoarchean high-pressure margarite-phengitic muscovite-chlorite corona mantled corundum in quartz-free high-Mg, $\mathrm{Al}$ phlogopite-chlorite schists from the Bundelkhand Craton, north central India; Contrib. Mineral. Petrol. 161 $511-530$.

Sarkar A, Paul D K and Potts P J 1996 Geochronology and geochemistry of the Mid-Archaean trondhjemitic gneisses from the Bundelkhand Craton, central India; In: Recent Researches in Geology and Geophysics of the Precambrians (ed.) A K Saha, Geol. Soc. India 16 76-92.

Sharma K K 2000 Evolution of Archaean Palaeoproterozoic crust of the Bundelkhand Craton, northern Indian shield; In: Research Highlights in Earth System Science (eds) Verma O P and Mahadevan T M, Special Publication of the Indian Geological Congress, Roorkee, pp. 95-105.

Sharma K K and Rahman A 1995 Occurrence and petrogenesis of Loda Pahar trondhjemitic gneiss from Bundelkhand Craton, central India: Remnant of an early crust; Curr. Sci. 69 613-616.

Singh S P 2012a Archean geology of Bundelkhand Craton, central India: An overview; J. Gondwana Geol. Mag. Spec. Publ. 13 125-140.

Singh S P 2012b Geochemical signatures of Archean felsic volcanism in the central part of Bundelkhand Craton, central India; Int. J. Adv. Earth Sci. 01 20-32.

Singh S P and Bhattacharya A R 2010 Signatures of Archaean E-W crustal-scale shears in the Bundelkhand massif, central India; J. Earth Sci. India 3 217225.

Singh S P and Dwivedi S B 2009 Garnet-sillimanitecordierite-quartz bearing assemblages from the early Archean supracrustal rocks of Bundelkhand massif, central India; Curr. Sci. 97 103-107.

Singh S P, Singh M M, Srivastava G S and Basu A K 2007 Crustal evolution in Bundelkhand area, central India; J. Him. Geol. 28 79-101.

Thompson A B 1976 Mineral reaction in pelitic rocks: 1 Prediction in $\mathrm{P}-\mathrm{T}-\mathrm{X}(\mathrm{Fe}-\mathrm{Mg})$ phase relations. II. Calculations of some $\mathrm{P}-\mathrm{T}-\mathrm{X}(\mathrm{Fe}-\mathrm{Mg})$ phase relations; Am. J. Sci. 276 401-454. 
Thompson A B 1982 Dehydration melting of pelitic rocks and the generation of $\mathrm{H}_{2} \mathrm{O}$ undersaturated granitic liquids; Am. J. Sci. 282 1567-1595.

Wells P R A 1979 Chemical and thermal evolution of Archean sialic crust, southern Greenland; J. Petrol. 20 $187-226$.

Whitney D L and Evans B W 2010 Abbreviations for names of rock-forming minerals; Am. Mineral. 95 185-187.
Wiedenbeck M and Goswami J N 1994 High precision ${ }^{207} \mathrm{~Pb} /{ }^{206} \mathrm{~Pb}$ zircon geochronology using a small ion microprobe; Geochim. Cosmochim. Acta 58 21352141.

Wu C M, Zhang Z and Ren L D 2004 Empirical garnet-biotite-plagioclase quartz (GBPQ) geobarometry in medium to high-grade metapelites; J. Petrol. 45 1907-1921.

MS received 26 June 2013; revised 6 July 2014; accepted 17 August 2014 